\title{
nature
}

biotechnology

\section{产 The responsibilities of growing up}

Since March 1996, when Bio/Technology was relaunched as Nature Biotechnology, biotech has gotten big. The combined revenues of the publicly quoted biotech companies in 1996 were around $\$ 10$ billion. A decade later, that figure is set to exceed $\$ 60$ billion according to investment bank Burrill \& Company. This sixfold growth in 10 years is largely due to huge revenue growth in an elite and small band of companies, including Amgen, Biogen-Idec, Chiron, Genentech, Genzyme, Gilead and Serono. It is these companies that are the flagships of the biotech sector. They are, and will continue to be, the public face of biotech. And they hold the key to the industry's most intractable and pernicious problem - the shortfall in funding for innovative science and technology.

Ten years ago, the amount of finance raised by public biotech firms and the revenue generated across the sector were virtually identical. In 2005 , in contrast, capital markets contributed only half as much to the coffers as revenue. Collectively, this would suggest that the sector is less at the mercy of investor fads and fickleness than before.

This picture of investor independence is too rosy, however. Biotech remains very top-heavy. The top seven firms listed above account for around $55 \%$ of the sector's revenue. These companies and around 50 others are profitable. But for firms lower down in the pecking order, access to finance remains hugely important. And for the smaller fry, the existence of a successful revenue-generating segment of biotech has been a double-edged sword.

On the positive side, the revenues and profits have encouraged investors. Every two years during the past decade, public investors have increased the amount they put into the sector by around $\$ 5$ billion. Biotech now is an investment reality, not a wild, hopeful dream. On the other hand, investors in 2006 are more picky about the sort of biotech in which they want to invest. The startups are still there, but now there are lots of more mature companies to choose from, too. And given a choice, investors tend to go for the safer bet.

According to Dow Jones VentureOne, US seed investments in biotech last year represented only $\$ 8$ million $(0.03 \%)$ of the total $\$ 2.4$ billion in venture capital (VC) invested in biopharmaceutical startups, down from $1 \%$ in 2001 . The rest went into late-stage or existing venture investments. In 2004, almost half of all Series A financings went to companies with drug candidates already in the clinic, rather than to innovative, proprietary science-based startups. Angel investors also retreated: only $50 \%$ of angel investment went into startups in 2004 , compared with $80 \%$ in the late nineties. Academic pedigree now apparently counts for little: the last time a venture from the University of California, San Francisco-perhaps the cradle of biotech—received VC funding was four years ago. Thus, investors have moved on. In 2006, they will assume the risks of clinical development but, increasingly, not the risks of earlier-stage research.
All of these factors mean the time is now ripe for the biggest biotech companies to exert a positive influence on the rest of their sector. The migration of venture capitalists represents a significant opportunity for biotech's bigger players to do better by doing good. Profitable companies ought to move swiftly to fill the funding gap, leveraging their substantial resources to claim a stake in the technologies and markets of the future.

The rationale for this is straightforward. Biotech startups conflate all kinds of risks: in technology, clinical performance, market acceptance, management inexperience or ineptitude, and the possibility of being unable to attract follow-on finance. By fleeing to later-stage companies, venture capitalists reduce the risks in technology, funding and management. Corporate venturing also reduces the risks, but in a more creative manner. With their activity structured in the right way, biotech corporate ventures could provide not only streams of much-needed cash to early companies, but also biotech-specific management experience and kudos, market presence and clinical expertise. They could also reduce the risks in business development. Biogen-Idec, for example, has said that by 2010 it expects fully half of its pipeline to come from in-licensed products; most of these product deals are likely to be made with biotech startups. Likewise, corporate ventures put large biotech back in touch with grassroots science and technology, which in turn can help their core business.

It is entirely possible, of course, that none of this will happen. Large biotech firms can continue to grow their businesses, at least in the short term, by developing their internal R\&D programs and simply shopping around for late-stage products. Like pharma companies before them, they might also be tempted to evergreen their patents (a subterfuge to renew an expired patent by citing a trivial new use or formulation), defend inflated prices for their drugs ( $\$ 100,000$ for a year's supply of Genentech's Avastin), and pay lip service to their ethics, turning a blind eye to insider trading scandals and multimillion-dollar fines for kickbacks to physicians.

But big biotech must realize that its business practices and strategy are front and center in the public eye. And its reputation affects public and investor confidence in all of biotech, big or small. That is why it is so important that large firms are seen to put something back.

The good news is that some of them are already doing it; Genentech formed GenenFUND in 2002, with MedImmune Ventures, Biogen-Idec's New Ventures and Amgen Ventures following soon after. But these funds are currently a drop in the ocean - collectively less than $\$ 500$ million over the next four to five years (around $0.4 \%$ of total annual investment in the biotech sector) — and there are few signs as yet that they are aggressive in pursuing enough early ventures to make a difference.

More of biotech's profitable companies need to adopt the corporate venturing strategy. And those that are already there need to see it not as paying homage to their pasts but as an investment in their futures. ID 